\title{
CONCEPTS AND METHODS OF MATHEMATICAL MODELLING OF PLANT GROWTH AND DEVELOPMENT. PLANT GERMINATION - PART II
}

\author{
Sławomir Kocira \\ Department of Machinery Exploitation and Management of Production Processes, \\ University of Life Sciences in Lublin, Lublin, Poland
}

*Corresponding author: e-mail: slawomir.kocira@up.lublin.pl

\begin{tabular}{|c|c|}
\hline ARTICLE INFO & ABSTRACT \\
\hline $\begin{array}{l}\text { Article history: } \\
\text { Received: June } 2018 \\
\text { Received in the revised form: } \\
\text { August } 2018 \\
\text { Accepted: September } 2018\end{array}$ & \multirow{2}{*}{$\begin{array}{l}\text { Interdisciplinary nature of scientific research with regard to agricul- } \\
\text { ture caused a development of mathematical modelling with regard to } \\
\text { plant growth and development. Application of mathematical sciences } \\
\text { in agriculture suits well the area of agricultural engineering which } \\
\text { covers the issues related to inter alia, application of mathematical } \\
\text { sciences. This article presents mathematical models, in which the } \\
\text { analysed system is described with mathematical formulas. The objec- } \\
\text { tive of the paper was to present the current state of knowledge on } \\
\text { mathematical methods in description and prediction of plant germina- } \\
\text { tion. Possibilities of the use of mathematical models and new chal- } \\
\text { lenges occurring in the description of plant germination were present- } \\
\text { ed. }\end{array}$} \\
\hline $\begin{array}{l}\text { Key words: } \\
\text { modelling in agriculture, } \\
\text { computer simulations, } \\
\text { mathematical modelling, } \\
\text { germination }\end{array}$ & \\
\hline
\end{tabular}

\section{Introduction}

Interdisciplinary nature of scientific research with regard to agriculture caused a development of mathematical modelling with regard to plant growth and development. According to Michałek (2008) one of the areas of research as a part of agricultural engineering is mathematical modelling of agri-biological processes. Also Cieśla et al., (2015) notice that application of mathematical sciences in agriculture is a domain of agricultural engineering, which includes inter alia, application of both mathematical, physical, agronomy, biophysics and molecular biology formulas in a widely understood research on agriculture.

Plant germination along with the process of their germination is the most crucial cultivation period which considerably affects the crop quality and yield. Thus, all the time, research aiming at facilitation of this stage of plant cultivation is carried out. Mathematical modelling is one of the so-called 'safe' methods that analyse predictions concerning the crop yield quality. Due to calculation models it is possible to quantitatively understand developmental mechanisms such as e.g. a detailed description of the plant growth dynamics. Additionally, their application enables system understanding of relations between aspects and stages of plant development and determination of the impact of, inter alia, physiological processes on other environmental factors on the plant growth. However, the biggest 
advantage resulting from the use of calculation models is the fact that this enables identification of areas where experimental research should be carried out and extended.

The objective of the paper was to present the current state of knowledge on mathematical methods in description and prediction of plant germination. Possibilities of the use of mathematical models and new challenges occurring in the description of plant germination were presented.

\section{Plant germination modelling}

Occurrence of seedlings is the most important phenological event which affects the growth and development success. Time, in which plant germination is observed often decides whether a plant competes successfully with neighbours, whether it is exposed to pests, and whether at the end of the vegetation season it matures correctly. There are many definitions of emergency, but the most arbitral one assumes that it is the first occurrence of a seedling on the soil surface (Forcella et al., 2000).

With so many important processes which decide on the plant growth, the precise understanding of the phenomenon of seedlings occurrence seems to be justified. What is surprising, plant germinations have not been yet investigated in a sufficient detail in order to enable credible prediction of even the most popular and important crop cultivars. Majority of scientists dealing with plants were happy with the calculation, estimation or prediction of the beginnings of germinations $\left(\mathrm{E}_{\mathrm{i}}\right)$ or the moment, where $50 \%$ of germinations were achieved $\left(\mathrm{E}_{50}\right)$. The problem is that emergency is a complex and constant function, which cannot be easily characterised with the simple index. Thus, in case of the crops growth, a dynamic approach to modelling is required. As a result, models of these plant germinations develop actively around the world both for crops as well as seeds (Forcella et al., 2000).

As in case of germination, also plant germination is determined with environmental conditions. In the literature, numerous models were suggested, that describe the impact of temperature and photoperiod on the phenological development of various crops (Weir et. al., 1984; Roberts and Summerfield, 1987; Hodges and Ritchie, 1991; Miglietta, 1992).

An empirical approach, where the development stage is related to one variable (integration of the development speed with environmental factors) seemed to be efficient in prediction of the plant growth (Keulen et al., 1995; Roberts and Summerfield, 1987). Research of Hodgson, (1978), Evans and Ludeke, (1987), Myers et al., (1982) present a mentioned approach to modelling in the description of the phenotype development of rapeseed. Cultivars adjusted to a determined environment will have a similar reactions to environmental conditions (Reinink et al., 1986). It means that this model may be directly used in all cultivars with similar developmental patterns. The procedure of calibration and validation may require a repetition in case of cultivars in other geographical regions. The model developed in this research may be used for practical purposes or as a module in the crops growth module (Habekotté, 1997).

From the perspective of modelling emergency, air and soil temperature in the field conditions should be taken into consideration. In this case data concerning germination must be changed into units (the index of germination speed), which would include both the scope and germination speed at each temperature. Such approach enabled formation of equations 
Concepts and methods - Part II ...

that simulate the impact of the average daily temperature of soil on the germination process. After a relevant time delay was included (elongation of hypocotyl) appearance of seedlings may be predicted with a specific probability. The soil temperature may be directly applied as a predictor of seedlings germination or it may be transformed into thermal time of soil (TT) i.e. in raising degrees of days. TT was successfully used in crops growth models (Angus et al., 1981). It probably took place because seeds are considerably homogeneous and usually are sown directly on humid soil in precise depths.

Thus, early tests of models based on TT predictions $E_{i}$ and $E_{50}$ of weeds were unsatisfactory (Boydston, 1989). The use of TT in emergency models has become a success when people became aware that occurrence may be represented by a straight, continuous sigmoidal curve, but only when upper few centimetres of soil in the field remained still moist or through hydration or through natural precipitation. It also proved that Gompertz', Weibull's, Richards' and logistic functions (Brown and Mayer, 1988), where TT occurs as an independent variable, may successfully describe plants germination. These functions improved prediction of the accumulated relative germination (CRE) of some species of weeds. Some researchers used complex extensions of these functions, such as a double Gompertz' curve (Kremer and Lotz, 1998). For a simple Gompertz equation coefficients are easily interpreted with TT prefix before delay, a and b parameters which represent the speed of germination growth after their start. Examples of TT application in CRE forecasts for weeds include such species as Digitaria ischmaeum (Fidanza et al., 1996) S. halepense (Benech et al., 1990) and 15 other taxons in computer software WeedCast (Forcella, 1998). Some researchers use calendar days as a time variable in CRE models (Cussans et. al., 1996). In those models the impact of temperature on the occurrence of seedlings is presented as a rather complex mathematical expression, which replace coefficients a and $b$. If calendar days are used as a time variable, the results were not as impressive as those from TT. According to literature data, emergency models that base on the impact of temperature, may be divided into two categories: mechanistic and empirical ones. Mechanistic models probably have the biggest chances for success in a longer perspective, due to the fact that they are based on known and experimentally estimated environmental impacts on the relax of seeds, soaking and elongation of a seedling (Oryokot et al., 1997). Despite the richness of laboratory research on germination and initial increase of seedlings, there are considerably not many mechanical models of the plant growth. Moreover, the number of scientific papers that compare simulation of models with factual observations of occurrence of seedlings in field conditions are also insufficient. However, existing mechanistic models were successful to some extent (Benech et al., 1990, Forcella, 1993; Roman et al., 2000). Mechanistic models may be very sensitive to specific seed features, which were used for generation of temperature sensitive, curves of germination speed. An empirical model is an alternative for mechanistic model, which may have various levels of empiricism. The most basic empirical model would be a simple representation of germinations in time averaged over the years. By joining the temperature component of time (TT) such empirical models become more mechanical, because the soil temperature determines partially the concept of thermal time. This variable has two precious features for forecasting germinations. Firstly, it has a considerable empirical and biologically rational explaining power, and secondly, it is simple for measuring and calculation. Not so long ago, the soil water potential has not have a simple and logic interpretation. Water in soil was to easily measurable and its accumulated impact on resting, sprouting and germination was difficult for comprehensive integration. 
These difficulties are presently the subject of scientific discussions in order to find relevant solutions. Integration of accumulated effects of water deficiency was presented in the "hydratime" concept. This idea was firstly presented and explained by Gummerson (1986) and then investigated and extended by Bradford (1995). Up to now, this concept has been used mainly for description of seeds germination in laboratory conditions and not for seedlings occurrence in the real field conditions. However, the idea of "hydrotime", especially combined with thermal time, extended to the concept of "hydrothermal" time is so attractive that its fast acceptance by scientists engaged in modelling of the occurrence of seedlings is predicted. Unfortunately, modelling of germination ability as a response to the seed sowing depth was not included in majority of models presented in the literature. Soil cultivation is strictly related with the seeds sowing method and is an important but indirect variable which regulates plant germination. However, in the recent years, few researchers documented an impact of cultivation on the seeds distribution in soil. In reality, there are presently models that simulate seeds distribution in the soil profile after one or few years of cultivation (Cousens and Moss, 1990; Grundy et al, 1996). Such type of models may be used for comparative research, especially when they are combined with models that predict plant germination in relation to the sowing depth, both for species with small and big seeds (Forcella et al., 1996). However, integration of this type of simple models with more dynamic emergency based on the microclimate still remains a challenge (Forcella et. al., 2000).

From the mechanistic point of view, another important aspect of germination modelling, which is scarce in literature, is elongation of a seedling before its occurrence over the soil surface. Soil temperature, water potential, impedance and many other factors affect the speed of elongation of epicotyls and hypocotyls. Elongation of seedlings may be modelled in the same manner as germination, with base temperature or thermal times. In reality, since cotyledons and hypocotyl lengths are constant measurements and not binar observations (germinating or not germinated) typically determined with the quantity by interest of probabilities, modelling is really easier for elongation of seedlings than for seeds germination. In reality, coefficients of seedlings elongation $(\mathrm{mm} /$ day) are often linear functions TT, at least within the scope of normal soil temperatures (Carberry and Campbell, 1989; Fyfield and Gregory, 1989; Oryokot et. al., 1997). Thus, although integration of seedlings elongation integration speeds progressing (Roman et. al., 2000), it mainly remains an important addition to plant germination models (Forcella et. al., 2000).

Results of field tests show also one of the reasons of delay in developing relevant emergency models, which consists in the investigation of processes that take place is soil within big time intervals. Colbach and Debaeke (1998) showed also the need to avoid the principles of a black box. The suggested models and division of plant life cycles into subproceses, taking into consideration a biological and physical impact of cultivation systems interacting with environmental factors. Forcella et al., (2000) analysed weed germination models indicating also the need to model element processes distinguishing such processes as resting, sprouting and growth before germination and also the impact of environmental processes and seed sowing depth in soil on those processes. Among those stages Grundy (2003) found out that hibernation is a process of "narrow throat" which often limits development and possibility of application of classical models. Another problematic aspect is a great variability of population observed in weed seeds, which is difficult for modelling. What is more, Grundy (2003) paid attention to the danger of overrating components of 
Concepts and methods - Part II ...

these models and to the problem of data introduction. Indeed, those complex models often require big and complicated sets of input variables which not often are complete and reliable (Colbach et al., 2005).

Newer models distinguish two main biological processes, i.e. sprouting and germination. But, in the germination process, division into growth before occurrence of seedlings over the soil surface takes place (Roman et al., 1999). Sprouting was modelled as a hydrothermal time function when the growth of sprouts and roots depended on temperature. Such research provide new and interesting information on the impact of environmental variables on sprouting and growth before germination, but they must be completed by differentiation and modelling of another biological processes (inter alia seeds survival and resting) and interactions with soil environment (the impact of seeds sowing depth and soil structure referred to the growth before germination) in order to obtain models of emergency useful at the field conditions levels.

\section{Conclusions}

The need for improvement of already existing plant germination models is mechanical integration of the microclimate and variables related to the sprouting speed and seedling elongation. It results from the fact that in order to predict occurrence of seedlings, precisely scaled step functions or the best constant integrated functions are required. Without such integration, scientists or farmers-practitioners will still manage crops with available but less than ideal information.

In the recent years a raise in the number of research on the use of artificial neural networks in the area of agricultural sciences, which mainly serve for combining problems with forecasting, was reported. We may observe a trend in application of artificial neural networks. Thus, the use of artificial neural networks for modelling various types of processes and classifications will in the future be a subject of majority of papers concerning SSN in the file of agricultural engineering (Francik et al., 2016).

The research on the existing models of process related to occurrence of plant seedlings showed many interesting approaches. So far no model has synthetized all those processes and approaches. Some precautions should be taken before aggregation of previous models. First of all, various plant species have various ecological requirements and behaviour in a real soil environment.

The basic input which the scientific system may bring in improvement of crops is ability to predict the environmental modulation of phenological phenomena in order to optimise the use of resources for the increase of production and higher profits. Such phenological forecasts enable minimization of negative environmental effects which affect reduction of crops such as low temperature and draught (Ritchie, 1993).

Models of plant growth simulation were recently used in numerous research in order to help farmers everyday to undertake decisions. In practice they were used for assessment of the impact of various management options in farms such as sowing time, plant distribution density, frequency of fertilizers application in various environmental conditions based on the long term average cropping probability and profit probability (Ungar, 1990, Carberry et al., 1993, Keating et al., 1993, Aggarwal 1993, Aggarwal and Kalra, 1994, Rötter and Dreiser, 1994, Jakubowski, 2011). In some, of the mentioned cases, model research led to ex- 
perimental research in the field in order to test the results predicted in simulations (Berge et al., 1994; Bouman, 1996). Those models proved themselves referred to specific plant species and cultivars. On this basis, numerous applications were formed, which enable management of farms with regard to making decisions of agronomic nature such as sowing and harvesting time or the use of crop protection substances. These applications are still being improved in relation to the progress in agricultural engineering and agronomy.

\section{References}

Aggarwal, P.K. (1993). Agro-ecological zoning using crop growth simulation models: characterization of wheat environments in India. F.W.T. Penning de Vries, P. Teng, K. Metselaar (Eds.), Systems approaches for sustainable agricultural development, Kluwer Academic Publishers, Dordrecht, The Netherlis, 97-109.

Aggarwal, P.K., Kalra, N. (1994). Analyzing the limitations set by climatic factors, genotype, and water and nitrogen availability on productivity of wheat II. Climatically potential yields and management strategies. Field Crops Research, 38, 93-103.

Angus, J.F., Cunningham, R.B., Moncur, M.W., Mackenzie, D.H. (1981). Phasic development in field crops. I. Thermal response in the seedling phase. Field Crops Research, 3, 365-378.

Benech Arnold, R.L., Ghersa, C.M., Sanchez, R.A., Insausti, P. (1990). A mathematical model to predict Sorghum halepense (L.) Pers. seedling emergence in relation to soil temperature. Weed Research, 30, 91-99.

Berge, N., Samaan, M., Juanole, G., Atamna J. (1994). Methodology for LAN modelling and analysis using Petri net based models. Proc. Int. Workshop on Modelling, Analysis and Simulation in Telecommunication Systems, Durham, NC, 269-275.

Bouman, B.A.M., van Keulen, H., van Laar, H.H., Rabbinge, R. (1996). The school of de Wit crop growth simulation models: a pedigree and historical overview Agricultural Systems, 52(2/3), 171-198.

Boydston, R.A. (1989). Germination and emergence of longspine sibur (Cenchrus longispinus). Weed Science, 37, 63-67.

Bradford, K.J. (1995). Water relations in seed germination. In: Kigel, J., Galili, G. (Eds.), Seed Development i Germination. Marcel Dekker, New York, pp. 351-396.

Brown, R.F., Mayer, D.G. (1988). Representing cumulative germination. 2. The use of the Weibull function and other empirically derived curves. Annals of Botany, 61, 127-138.

Carberry, P.S., Campbell, L.C. (1989). Temperature parameters useful for modeling the germination and emergence of pearl millet. Crop Science, 29, 220-223.

Carberry, P.S., Muchow, R.C., McCown, R.L. (1993). A simulation model of kenaf for assisting fibre industry planning in northern Australia. IV. Analysis of climatic risk. Australian Journal of Agricultural Research, 44, 713-730.

Cieśla A., Kraszewski, W., Skowron, M., Syrek P. (2015). Wpływ działania pola magnetycznego na kiełkowanie nasion. Przeglad Elektrotechniczny, 91(1), 125-128.

Colbach, N., Debaeke, P. (1998). Integrating crop management and crop rotation effects into models of weed population dynamics: a review. Weed Science, 46, 717-728.

Colbach, N., Dürr, C., Roger-Estrade, J., Caneill, J. (2005). How to model the effects of farming practices on weed emergence. Weed Research, 45, 2-17.

Cousens, R., Moss, S.R. (1990). A model of the effects of cultivation on the vertical distribution of weed seeds within the soil. Weed Research, 30, 61-70.

Cussans, G.W., Raudonius, S., Brain, P., Cumberworth, S. (1996). Effects of depth of seed burial and soil aggregate size on seedling emergence of Alopecurus myosuroides, Galiumaparine, Stellaria media, i wheat (Triticum aestivum). Weed Research, 36, 133-142. 
Concepts and methods - Part II ...

Evans, E.J., Ludeke, F. (1987). Effect of sowing date on the flower and pod development of four winter oilseed rape cultivars. Annals of Applied Biology, 110, 170-171.

Fidanza, M., Dernoeden, P.H., Zhang, M. (1996). Degree-days for predicting smooth crabgrass emergence in cool-season turf. Crop Science, 36, 990-996.

Forcella, F. (1993). Seedling emergence model for velvetleaf. Agronomy Journal, 85, 929-933.

Forcella, F. (1998). Real-time assessment of seed dormancy and seedling growth for weed management. Seed Science Research, 8, 201-209.

Forcella, F., Benech-Arnold, R.L., Sánchez, R.A., Ghersa, C.M. (2000). Modeling seedling emergence. Field Crops Research, 67, 123-139.

Forcella, F., Durgan, B.R., Buhler, D.D. (1996). Management of weed seedbanks. In: Streibig, J. (Ed.), Proceedings of the Second International Weed Control Congress. International Weed Science Society, Copenhagen, 21-26.

Francik, S., Ślipek, Z., Frączek, J., Knapczyk, A. (2016). Present trends in research on application of artificial neural networks in agricultural engineering. Agricultural Engineering, 20(4), 15-25.

Fyfield, T.P., Gregory, P.J. (1989). Effects of temperature and water potential on germination, radicle elongation and emergence of mungbean. Journal of Experimental Botany, 40, 667-674.

Grundy, A.C. (2003). Predicting weed emergence: a review of approaches and future challenges. Weed Research, 43, 1-11.

Grundy, A.C., Mead, A., Bond, W. (1996). Modelling the effects of weed-seed distribution in the soil profile on seedling emergence. Weed Research, 36, 375-384.

Gummerson, R.J. (1986). The effect of constant temperatures and osmotic potential on the germination of sugar beet. Journal of Experimental Botany, 37, 729-741.

Habekotté, B. (1997). A model of the phenological development of winter oilseed rape. Field Crops Research, 54, 127-136.

Hodges, T., Ritchie, J.T. (1991). The CERES-Wheat Phenology Model. Hodges T. (Ed.), Predicting Crop Phenology, CRC Press, Boston.

Hodgson, A.S. (1978). Rapeseed adaptation in Northern New South Wales. II. Predicting plant development of Brassica campestris L. and Brassica napus L. and its implications for planting time, designed to avoid water deficit and frost. Australian Journal of Agricultural Research, 29, 711-726.

Jakubowski, T. (2011). Model plonowania roślin ziemniaka (Solanum tuberosum L.) wyrosłych z sadzeniaków napromienionych mikrofalami. Acta Agrophysica, 17(2), 311-323.

Keating, B.A., McCown, R.L., Wafula, B.M. (1993). Adjustment of nitrogen inputs in response to a seasonal forecast in a region of high climatic risk. F.W.T. Penning de Vries, P. Teng, K. Metselaar (Eds.), Systems approaches for sustainable agricultural development, Kluwer Academic Publishers, Dordrecht, The Netherlis.

Kremer, E., Lotz, L.A. (1998). Germination and emergence characteristics of triazine-susceptible and triazine-resistant biotypes of Solanum nigrum. Journal of Applied Ecology, 35, 302-310.

Michałek, R. (2008). Przyszłość inżynierii rolniczej jako nauki i kierunku kształcenia. Inżynieria Rolnicza, 1(99), 297-302.

Miglietta, F. (1992). Simulation of wheat ontogenesis. Ph.D. Thesis, Agricultural University Wageningen i Accademia deiGeorgofili, Italy.

Myers, L.F., Christian, K.R., Kirchner, R.J. (1982). Flowering responses of 48 lines of oilseed rape (Brassica spp.) to vernalization i daylenth. Australian Journal of Agricultural Research, 33, 927-936.

Oryokot, J.O.E., Murphy, D.D., Thomas, A.G., Swanton, C.J. (1997). Temperature- and moisterdependent models of seed germination and shoot elongation in green and redroot pigweed (Amaranthus powellii, A. retroflexus). Weed Science, 45, 488-496.

Ritchie, J.T. (1993). Genetic specific data for crop modeling F. Penning de Vries, P. Teng, K. Metselaar (Eds.), Systems Approaches for Agricultural Development, Kluwer Academic Press, Boston. 77-93. 
Sławomir Kocira

Roberts, E.H., Summerfield R.J. (1987). Measurements i prediction of flowering in annual crops. Atherton J.G. (Ed.), Manipulation of Flowering, Butterworth, London.

Roman, E.S., Murphy, S.D., Swanton, C.J. (2000). Simulation of Chenopodium album seedling emergence. Weed Science, 48, 217-224.

Roman, E.S., Thomas, A.G., Murphy, S.D., Swanton, C.J. (1999). Modelling germination and seedling elongation of common lambsquarters (Chenopodium album). Weed Science, 47, 149-155.

Rötter, R., Dreiser C. (1994). Extrapolation of maize fertiliser trial results by using crop-growth simulation: results for Murang'a District, Kenya. L.O. Fresco, L. Stroosnijder, J. Bouma, H. van Keulen (Eds.). The future of the li: mobilising and integrating knowledge for li use options, John Wiley \& Sons Ltd, West Sussex, UK.

Ungar, E.D. (1990). Management of agropastoral systems in a semiarid region Simulation Monographs. PUDOC, Wageningen, The Netherlis.

Weir, A.H., Braggs, P.L., Porter, J.R., Rayner, J.H. (1984). A winter wheat crop simulation model without water or nutrient limitations. The Journal of Agricultural Science, 102, 371-382.

\section{KONCEPCJE I METODY MODELOWANIA MATEMATYCZNEGO PROCESÓW WZROSTU I ROZWOJU ROŚLIN. WSCHODY ROŚLIN - CZESŚ́ II}

Streszczenie. Interdyscyplinarność badań naukowych w zakresie rolnictwa przyczyniła się do rozwoju modelowania matematycznego w zakresie wzrostu i rozwoju roślin. Stosowanie nauk matematycznych w rolnictwie wkomponowuje się w obszar inżynierii rolniczej, która to w swoim zakresie obejmuje zagadnienia związane m.in. z zastosowaniem nauk matematycznych. W artykule tym zostały przedstawione modele matematyczne, w których analizowany system jest opisany przy zastosowaniu formuł matematycznych. Celem pracy było przedstawienie dotychczasowego stanu wiedzy na temat metod matematycznych w opisywaniu i prognozowaniu wschodów roślin. Przedstawiono możliwości wykorzystania modeli matematycznych i nowe wyzwania pojawiające się w opisie wschodów roślin.

Słowa kluczowe: modelowanie w rolnictwie, symulacje komputerowe, modelowanie matematyczne, wschody 